\title{
Alternative lengthening of telomeres is the major telomere maintenance mechanism in astrocytoma with isocitrate dehydrogenase 1 mutation
}

\author{
Monica Sofia Ventura Ferreira ${ }^{1} \cdot$ Mia Dahl Sørensen ${ }^{2,3} \cdot$ Stefan Pusch $^{4,5,6} \cdot$ Dagmar Beier $^{3,7} \cdot$ Anne-Sophie Bouillon ${ }^{1}$. \\ Bjarne Winther Kristensen $^{2,3} \cdot$ Tim Henrik Brümmendorf $^{1} \cdot$ Christoph Patrick Beier $^{3,7}$ (i) $\cdot$ Fabian Beier $^{1}$ (D)
}

Received: 24 October 2019 / Accepted: 7 January 2020 / Published online: 20 January 2020

(C) The Author(s) 2020

\begin{abstract}
Purpose Isocitrate dehydrogenase 1 (IDH1) mutations are associated with improved survival in gliomas. Depending on the IDH1 status, TERT promoter mutations affect prognosis. IDH1 mutations are associated with alpha-thalassemia/mental retardation syndrome X-linked (ATRX) mutations and alternative lengthening of telomeres (ALT), suggesting an interaction between IDH1 and telomeres. However, little is known how IDH1 mutations affect telomere maintenance.

Methods We analyzed cell-specific telomere length (CS-TL) on a single cell level in 46 astrocytoma samples (WHO II-IV) by modified immune-quantitative fluorescence in situ hybridization, using endothelial cells as internal reference. In the same samples, we determined IDH1/TERT promoter mutation status and ATRX expression. The interaction of IDH1 ${ }^{\mathrm{R} 132 \mathrm{H}}$ mutation and CS-TL was studied in vitro using an IDH1 ${ }^{\mathrm{R} 132 \mathrm{H}}$ doxycycline-inducible glioma cell line system.

Results Virtually all ALT ${ }^{\text {positive }}$ astrocytomas had normal TERT promoter and lacked ATRX expression. Further, all $\mathrm{ALT}^{\text {positive }}$ samples had IDH1 ${ }^{\mathrm{R} 132 \mathrm{H}}$ mutations, resulting in a significantly longer CS-TL of IDH1 ${ }^{\mathrm{R} 132 \mathrm{H}}$ gliomas, when compared to their wildtype counterparts. Conversely, TERT promotor mutations were associated with IDH ${ }^{\text {wildtype }}$, ATRX expression, lack of ALT and short CS-TL. ALT, TERT promoter mutations, and CS-TL remained without prognostic significance, when correcting for IDH1 status. In vitro, overexpression of $\mathrm{IDH}^{\mathrm{R} 132 \mathrm{H}}$ in the glioma cell line $\mathrm{LN} 319$ resulted in downregulation of ATRX and rapid TERT-independent telomere lengthening consistent with ALT.

Conclusion ALT is the major telomere maintenance mechanism in $\mathrm{IDH}^{\mathrm{R} 132 \mathrm{H}}$ mutated astrocytomas, while TERT promoter mutations were associated with IDH ${ }^{\text {wildtype }}$ glioma. IDH1 ${ }^{\mathrm{R} 132 \mathrm{H}}$ downregulates ATRX expression in vitro resulting in ALT, which may contribute to the strong association of IDH1 ${ }^{\mathrm{R} 132 \mathrm{H}}$ mutations, ATRX loss, and ALT.
\end{abstract}

Keywords Isocitrate dehydrogenase · D2HG · Telomerase · Telomere length · Q-FISH · TERT promoter · ALT · ATRX

Christoph Patrick Beier and Fabian Beier have contributed equally to this work.

Electronic supplementary material The online version of this article (https://doi.org/10.1007/s11060-020-03394-y) contains supplementary material, which is available to authorized users.

Fabian Beier

fbeier@ukaachen.de

1 Department of Haematology, Oncology, Medical Faculty, RWTH Aachen, Pauwelsstrasse 30, 52074 Aachen, Germany

2 Department of Pathology, University Hospital Odense, Sdr. Boulevard 29, 5000 Odense, Denmark

3 Department of Clinical Research, University of Southern Denmark, Sdr. Boulevard 29, 5000 Odense, Denmark

\section{Introduction}

Gliomas are the most common primary brain tumors in adults and represent a histologically defined entity with a high molecular heterogeneity determining prognosis and response

4 Department of Neuropathology, University of Heidelberg, Heidelberg, Germany

5 Clinical Cooperation Unit Neuropathology, German Cancer Research Center (DKFZ), Heidelberg, Germany

6 German Cancer Consortium (DKTK), Heidelberg, Germany

7 Department of Neurology, University Hospital Odense, Sdr. Boulevard 29, 5000 Odense, Denmark 
to therapy $[1,2]$. Along this line, determination of isocitrate dehydrogenase (IDH) 1 mutation status became mandatory in the updated 2016 WHO classification [3]. IDH1 mutations are driver mutations of low-grade gliomas and found in $80 \%$ [4] but are not detectable in primary glioblastoma (GBM) [2, 5]. The most common IDH1 mutations in glioma (>95\%) result in an amino acid substitution at arginine 132 (R132), which resides in the enzyme's active site [4]. Despite the abundance of evidence in support of a major pathophysiological and prognostic role of IDH1 mutations [6-8], the precise mechanism of how IDH1 mutations modulate malignancy is still not completely understood. While IDH1 has a major role in the citric acid cycle, $\mathrm{R} 132 \mathrm{H}$ mutation $\left(\mathrm{IDH}^{\mathrm{R} 132 \mathrm{H}}\right.$ ) results in a gain of function; $\mathrm{IDH} 11^{\mathrm{R} 132 \mathrm{H}}$ catalyzes conversion of alpha-ketoglutarate into the oncometabolite D-2-hydroxyglutarate (D2HG) [9]. D2HG inhibits dioxygenases that depend on alpha-ketoglutarate, like Ten-eleven translocation methylcytosine dioxygenase 1 (TET1) and histone-lysine demethylases [10]; this results in increased $\mathrm{CpG}$ island methylation [11] and a stable reshaping of the epigenome ( $\mathrm{CpG}$ island methylation phenotype, CIMP) changing transcriptional programs and altering the differentiation state [12].

Telomeres determine the proliferative capacity of mammalian cells. Telomere length (TL) shortens with each cell division until cell proliferation is arrested once the maximal number of cell divisions is reached ("Hayflick limit"). In case of further replication, cells undergo chromosomal instability and induction of apoptosis. Expression of human telomerase reverse transcriptase (TERT) allows for the stabilization and elongation of telomeres. Telomere maintenance mechanisms (TMM) are necessary for immortality of cancer cells by overcoming genetic instability associated with critical telomere shortening [13].

TERT promoter mutations (TERTp ${ }^{\mathrm{mut}}$ ) are common in glioma and found in 80\% of all primary GBM [14-16], representing one possible TMM. TERTp ${ }^{\text {mut }}$ disrupt the tight transcriptional suppression of TERT in somatic cells resulting in increased TERT expression and telomerase activity in vitro in glioma [17].

A mechanism of homologous recombination [18] to maintain TL, known as "alternative lengthening of telomeres" (ALT), was also identified in gliomas. About $20-63 \%$ of adult low-grade glioma and $11 \%$ of adult GBM use ALT as an additional mechanism for telomere maintenance [19, 20]. Dysfunction of the $\alpha$-thalassemia/mental retardation syndrome $\mathrm{X}$-linked (ATRX)/death-associated protein 6 (DAXX) complex is known to result in ALT along with more widespread genomic destabilization [21-23]. ATRX and DAXX are central components of a chromatin-remodeling complex required for the incorporation of $\mathrm{H} 3.3$ histone proteins into the telomeric regions of chromosomes [24, 25]. 75\% of grade II-III astrocytomas and secondary GBM harbor ATRX abberations [26-28] linking IDH1 mutations with ATRX and ALT.
Despite the strong associations observed, few data is available how the different pathways interact on telomere maintenance. The aim of this study was to investigate the interplay among IDH1, TL, ATRX and TERT/ALT using a newly developed distinctive methodology that allowed determination of glioma cell-specific telomere length (CS-TL) on a single cell level.

\section{Materials and methods}

\section{Patients}

Tissue samples from 46 astrocytoma patients were included for the study. The Regional Committee on Health Research Ethics approved the study for Southern Denmark (S2DO90080) and Danish Data Protection Agency (file number: 2009-41-3070) and all patients provide informed consent. The use of tissue was not prohibited by any patient according to the Danish Tissue Application Register. All methods were performed in accordance with the relevant guidelines and regulations. All patients underwent primary surgery between 1991 and 2005 at the Department of Neurosurgery, Odense University Hospital, Denmark. All cases were independently reviewed and reclassified by M.D.S and B.W.K. (senior neuropathologist) according to the 2016 WHO guidelines [2] as described in [29]. Clinical data were extracted from the respective electronic patient journal. Clinical and neuropathological characteristics of the astrocytoma patients are shown in Table 1.

\section{Immunohistochemistry}

Formaldehyde-fixed paraffin embedded (FFPE) sections of three $\mu \mathrm{m}$ from pre-surgery tissue biopsies were used for this study. FFPE sections were stained as described previously using primary antibodies against IDH $1^{\mathrm{R} 132 \mathrm{H}}(\mathrm{H} 09,1: 100$, Dianova, Germany) [30] and ATRX [29] (HPA001906, 1:100, Atlas Antibodies, Sweden) epitopes.

\section{DNA extraction, polymerase chain reaction and mutational analysis by sequencing}

Mutations in the TERT promoter region were identified by PCR and Sanger sequencing as described previously [31]. The detailed protocol can be found in the Supplementary Materials and methods.

\section{Cell culture, proliferation and clonogenicity}

For the cell culture experiments the doxycycline-inducible GBM cell line LN319 expressing IDH1 wildtype (IDH1 ${ }^{\text {WT }}$ ) and IDH1 ${ }^{\mathrm{R} 132 \mathrm{H}}$ was used. Cells were cultured in Dulbecco's 
Table 1 Patient characteristics and pathology

\begin{tabular}{|c|c|c|c|c|}
\hline & Diffuse astrocytoma & Anaplastic astrocytoma & Glioblastoma & All \\
\hline Patients (n) & 24 & 9 & 13 & 46 \\
\hline \multicolumn{5}{|l|}{ Age } \\
\hline Mean & 45.2 & 47.6 & 65.3 & 51.4 \\
\hline Range & $2.6-78.5$ & $29.5-71.0$ & $49.4-77.5$ & $2.6-78.5$ \\
\hline \multicolumn{5}{|l|}{$\operatorname{Sex}(n)$} \\
\hline Male & $14(58.3 \%)$ & $3(33.3 \%)$ & $10(76.9 \%)$ & $27(58.7 \%)$ \\
\hline Female & $10(42.7 \%)$ & $6(66.7 \%)$ & $3(23.1 \%)$ & $19(41.3 \%)$ \\
\hline \multicolumn{5}{|l|}{ Status (n) } \\
\hline Alive & $3(12.5 \%)$ & $0(0 \%)$ & $0(0 \%)$ & $3(6.5 \%)$ \\
\hline Dead & $21(87.5 \%)$ & $9(100 \%)$ & $13(100 \%)$ & $43(93.5 \%)$ \\
\hline \multicolumn{5}{|c|}{ Overall survival (months) } \\
\hline Median & 76.9 & 24.0 & 7.5 & 32.6 \\
\hline Range & $3.4-280.0$ & $4.7-48.8$ & $1.5-34.2$ & $1.5-280.0$ \\
\hline \multicolumn{5}{|l|}{ IDH1 status (n) } \\
\hline Mutated & $18(75.0 \%)$ & $4(44.4 \%)$ & $1(7.7 \%)$ & $23(50.0 \%)$ \\
\hline Wildtype & $6(25.0 \%)$ & $5(55.6 \%)$ & $12(92.3 \%)$ & $23(50.0 \%)$ \\
\hline \multicolumn{5}{|l|}{ ATRX status (n) } \\
\hline Loss & $20(83.3 \%)$ & $4(44.4 \%)$ & $4(30.8 \%)$ & $28(60.9 \%)$ \\
\hline Retained & $4(16.7 \%)$ & $5(55.6 \%)$ & $9(69.2 \%)$ & $18(39.1)$ \\
\hline \multicolumn{5}{|l|}{ 1P/19Q status (n) } \\
\hline CO-DEL & 0 & 0 & 0 & 0 \\
\hline 1P-DEL & 0 & $1(11.1 \%)$ & $1(7.7 \%)$ & $2(4.3 \%)$ \\
\hline 19-DEL & 0 & 0 & 0 & 0 \\
\hline NON-DEL & $5(20.8 \%)$ & $2(22.2 \%)$ & $2(15.3 \%)$ & $9(19.6 \%)$ \\
\hline Not determined & $19(79.2 \%)$ & $6(66.7 \%)$ & $10(76.9 \%)$ & $35(76.0 \%)$ \\
\hline \multicolumn{5}{|c|}{ hTERT promoter mutation } \\
\hline Mutated & $6(25.0 \%)$ & $3(33.3 \%)$ & $9(69.2 \%)$ & $18(39.1 \%)$ \\
\hline $\mathrm{C} 228 \mathrm{~T}$ & $5(83.3 \%)$ & $2(66.7 \%)$ & $8(88.9 \%)$ & $15(83.3 \%)$ \\
\hline $\mathrm{C} 250 \mathrm{~T}$ & $1(16.7 \%)$ & $1(33.3 \%)$ & $1(11.1 \%)$ & $3(16.7 \%)$ \\
\hline None & $17(75.0 \%)$ & $5(55.6 \%)$ & $4(30.8 \%)$ & $26(56.5 \%)$ \\
\hline Not determined & $1(4.1 \%)$ & $1(11.1 \%)$ & 0 & $2(4.3 \%)$ \\
\hline \multicolumn{5}{|l|}{ ALT status } \\
\hline Negative & $12(50 \%)$ & $5(55.6 \%)$ & $12(92.3 \%)$ & $29(63.0 \%)$ \\
\hline Positive & $12(50 \%)$ & $4(44.4 \%)$ & $1(7.7 \%)$ & $17(37.0 \%)$ \\
\hline \multicolumn{5}{|c|}{ KI67 proliferation rate } \\
\hline Mean $(\%)$ & 3.3 & 9.7 & 10.2 & 6.7 \\
\hline Range (\%) & $0-30$ & $3-20$ & $2-35$ & $0-35$ \\
\hline \multicolumn{5}{|l|}{ CS-TL } \\
\hline Median & 11.8 & 13.6 & 3.5 & 11.0 \\
\hline Range & -1.1 to 36.7 & -3.9 to 31.5 & -6.0 to 25.2 & -6.0 to 36.7 \\
\hline
\end{tabular}

Modified Eagle Medium (DMEM) (Gibco, Germany) supplemented with $10 \%$ tetracycline-free fetal calf serum (FCS) (Clontech, USA) and standard antibiotics (Gibco, Germany). $1 \mu \mathrm{M}$ doxycycline was used (Sigma Aldrich, Germany) to induce expression. Cell proliferation was assessed using the CellTiter-Blue Assay (Promega, Germany) as described previously [32] using the FLUOstarOPTIMA (BMG Labtech, Germany) fluorometer.
For colony-forming unit assays, 2500 cells/well were seeded in a 6-well format for 10 days before colonies were fixed and stained with Cristal Violet (Sigma, Germany). For agar assays, 8000 cells/well were seeded in a 6-well format and incubated for 3 weeks before cells were stained with Cristal Violet. Images were acquired with a Cool Snap ${ }^{\mathrm{TM}}$ HQ2 digital camera (Photometrics, USA) on an Axiophot 2 microscope (Carl Zeiss, Germany). Quantification was done 
using ImageJ software (open source). Results are means of three repeated experiments.

\section{(D)-2-hydroxyglutarate (DGH2) assay}

The DGH2 assay used was based on an enzymatic assay as previously described [9]. The detailed protocol can be found in the Supplementary Materials and methods.

\section{RNA extraction, cDNA synthesis and mRNA expression}

Determination of TERT and ATRX mRNA expression was carried out as described presviously[32]. Gene expression is expressed in fold change according to the $2^{-\Delta \Delta c_{t}}$ method. Additional information can be found in the Supplementary Materials and methods.

\section{Quantitative fluorescence in situ hybridization (Q-FISH)}

TL analysis was done by a modified protocol of immunoquantitative fluorescence in situ hybridization (Q-FISH) as previously described [31-35]. FFPE sections of the cohort were deparaffinized and rehydrated before antigen retrieval in $10 \mathrm{mM}$ citrate buffer (pH6.0). Slides were permeabilized with $0.2 \%$ Triton X-100 and blocked for $30 \mathrm{~min}$ in serumfree buffer (Rotiblock 1:10, Roth, Germany). Actin fibers were first stained with primary antibody mouse anti-human alfa-SMA (1:200, DAKO, Germany) and a goat anti-mouse Alexa Fuor 633 (1:100, Thermo Fisher, Germany) as secondary antibody. Next, cells were post-fixed in formalin for $30 \mathrm{~s}$ and dehydrated with increasing ethanol series before telomere staining. For cells in culture, cells were recovered from culture, fixed in methanol:acetic acid (3:1), cytospin, air dried and dehydrated with ethanol before telomeres were stained. Telomere staining consisted in providing a hybridization mixture containing the Cy3-(C3TA2) peptide nucleic acid (PNA) probe (Panagene, South Korea) to the slides for $3 \mathrm{~min}$ at $85^{\circ} \mathrm{C}$ for DNA denaturation. Slides were then hybridized for $2 \mathrm{~h}$ at room temperature in a humidified chamber. Next, slides were washed with a formamide-based buffer, DAPI stained, and mounted with Vectashield antifade mounting medium (Vector Labs, USA). Fluorescence was acquired with the high-resolution laser-scanning microscope LSM710 (Zeiss, Germany). H\&E stained sections were analyzed in parallel for all cases to identify tumor areas. Fluorescent image capture was done with $\times 63$ optical magnification and $\times 1.2$ zoom. A multi-tracking mode of $0.5 \mu \mathrm{m}$-steps was used to acquire images of DAPI, Cy3 and Alexa Fluor
633 stainings. Maximum projection of five single consecutive steps of $1.2 \mu \mathrm{m}$ each was done for TL quantification using Definiens software (Definiens, Germany). Nuclei and telomeres were detected based on the respective DAPI and Cy3 intensity. Alfa-SMA was used to identify endothelial cells that were used as an internal control to correct for TL inter-individual variability [32-38]. A mean number of 150 tumor cells and 100 endothelial cells were assessed per case. To determine the tumor cell-specific telomere length (CS$\mathrm{TL}$ ), the difference ( $\Delta$ telomere length) between the TL of astrocytoma cells and the TL of endothelial cells was calculated and designated in arbitrary units (a.u.) of fluorescence.

\section{ALT assessment}

All astrocytoma cases were assessed for the presence of ALT phenotype using telomere Q-FISH staining. ALT positivity was identified by large, ultrabright, clumpy, intranuclear foci of telomere FISH signals, as previously described [20, 21]. A tumor was defined as ALT-positive, when the following two criteria were fullfilled: (1) the presence of ultra-bright intranuclear foci of telomere FISH signals (ALT-associated telomeric foci), with integrated total signal intensities for individual foci being $>10$-fold the mean signal intensities per cell of all telomeric signals from endothelial cells within the same case and (2) the number of cells with ALT-associated telomeric foci being $1 \%$ or more of the total number of tumor cells assessed per case [20,21].

\section{ATRX and TERT Immunofluorescence and western blotting}

Immunofluorescence for ATRX and TERT followed previously published protocols $[32,35,37]$. Western blot was carried out according to previous published standard protocols. The detailed protocol can be found in the Supplementary Materials and methods.

\section{Statistical analysis}

The data was collected via Microsoft Excel 2007 and analyzed using Stata version 15 (StataCorp LP, USA) or GraphPad Prism 5.0 (GraphPad Software Inc, USA). ANOVA with Bonferroni correction was used for comparison of more than two groups. Student's unpaired $t$ test was used to compare differences between two groups. Fisher's exact test was used to analyze categorical data. Overall survival was defined from the day of initial surgery until death or date of censoring (July 1st, 2018). Survival data were analysed and we using Kaplan-Meier and the multivariate Cox regression 
A

Pathol.

$\mathrm{IDH}$

ATRX

TERT

ALT

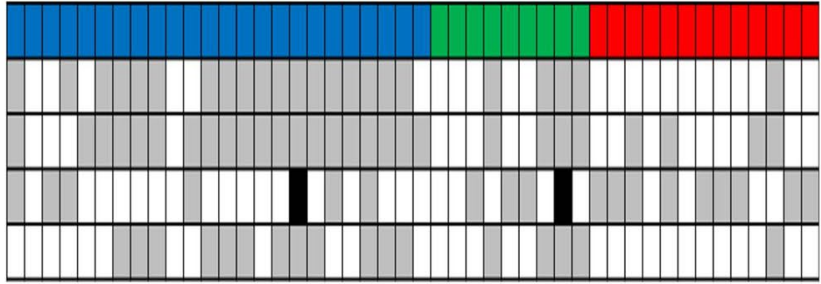

Diffuse astrocytoma

Anaplastic astrocytoma

Glioblastoma

IDH $^{\text {R132H }}$, ATRX loss $^{\text {, TERT }}{ }^{\text {mut }}$, ALT $^{\text {pos }}$

IDH $^{\text {wt }}$, ATRX $^{\text {ret }}$, TERT $^{w t}$, ALT $^{\text {neg }}$

not determined

B

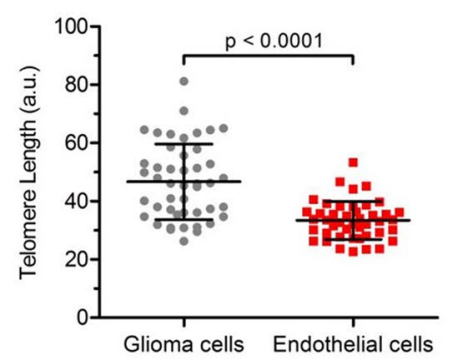

C

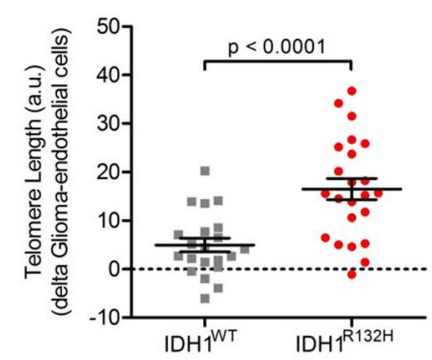

D

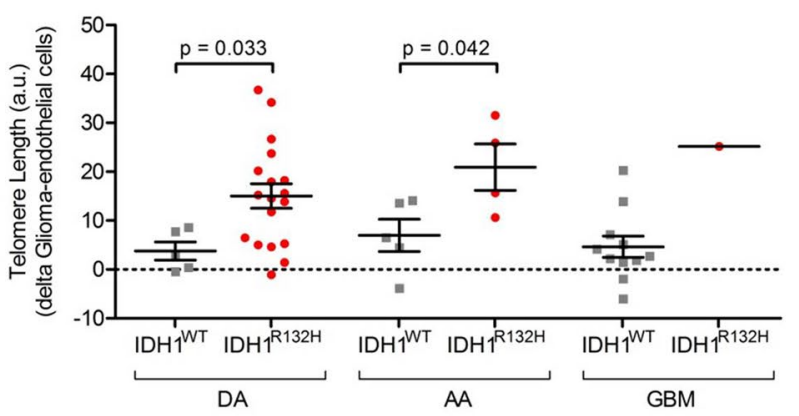

$\mathbf{E}$
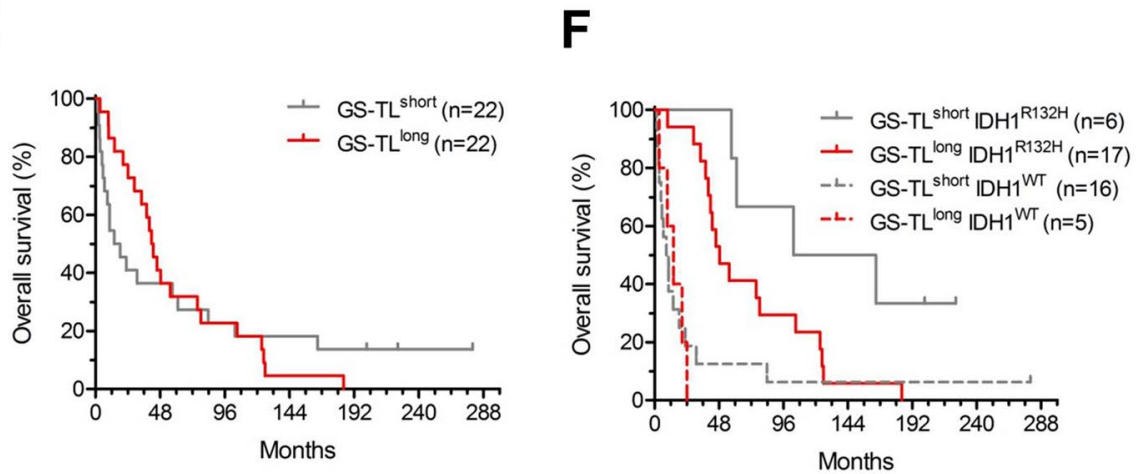

Fig. 1 Glioma cell-specific telomere length in IDH1 ${ }^{\text {WT }}$ and $\mathrm{IDH} 1^{\mathrm{R} 132 \mathrm{H}}$ glioma. a Overview of biomarkers status in glioma patients $(n=46)$. b Telomere length in glioma vs endothelial cells. c Telomere length (in arbitrary units, a.u.) in IDH $1^{\mathrm{WT}}$ and $\mathrm{IDH} 1^{\mathrm{R} 132 \mathrm{H}}$ glioma samples; d Telomere length (in a.u.) in $\mathrm{IDH} 1^{\mathrm{WT}}$ and $\mathrm{IDH} 1^{\mathrm{R} 132 \mathrm{H}}$ glioma stratified by WHO tumor grade (DA diffuse astro- cytoma, $A A$ anaplastic astrocytoma, $G B M$ gliobastoma multiform); e Kaplan-Meier survival curves (in months) of patients with CS-TL below (CS-TL ${ }^{\text {short }}$ ) or above median; f Kaplan-Meier survival curves (in months) of patients with CS-TL below (CS-TL ${ }^{\text {short}}$ ) or above median stratified based on IDH1 mutational status 
model to adjust for age, WHO grade, and IDH1 status. Survival curves were compared using the log-rank test.

\section{Results}

\section{Association of IDH1 ${ }^{\mathrm{R} 132 \mathrm{H}}$ mutations and telomere length}

The incidence of IDH1 ${ }^{\mathrm{R} 132 \mathrm{H}}$ mutations in our cohort was 50\% (Fig. 1a, Table 1). Single cell-based telomere analysis using modified immuno-Q-FISH (Supplementary Figure $\mathrm{S} 1 \mathrm{~A}, \mathrm{~B})$ revealed significantly longer TL in astrocytoma as compared to endothelial cells $(p<0.0001)$ and a substantial inter-individual variability (Fig. 1b). To overcome this issue, we used the endothelial cells as internal control, which allowed correction of the TL of astrocytoma cells for age and for inter-individual variability (i.e. CS-TL). The CS-TL was significantly longer in $\mathrm{IDH} 1^{\mathrm{R} 132 \mathrm{H}}$-mutated tumors as compared to IDH $1^{\text {WT }}$ tumors (Fig. 1c) irrespective of tumor grade (Fig. 1d), while there were no significant differences among the different tumor types $(\mathrm{p}=0.19$, Supplementary Figure S1C). IDH1 ${ }^{\mathrm{R} 132 \mathrm{H}}$ mutation was significantly associated with improved patient survival (HR $0.28 ; 95 \%$ CI $0.14-0.50 ; p<0.001$, Supplementary Figure S1C) with similar tendency (HR $0.47 ; 95 \%$ CI $0.21-1.08 ; p=0.076$ ) when adjusting for age and WHO grade. CS-TL did not significantly correlate with prognosis (HR 0.98; $\mathrm{p}=0.95$ ) (Fig. 1e). However, when dichotomizing patients based on IDH1 status and CS-TL, patients with IDH $1^{\mathrm{R} 132}$-mutated tumors and long CS-TL had significantly poorer survival than patients with $\mathrm{IDH} 1^{\mathrm{R} 132}$-mutated tumors and short CS-TL (HR 1.80; 95\% CI $1.03-3.16 ; p=0.030$, Fig. 1F). No significant prognostic value was found for patients with $\mathrm{IDH}^{\mathrm{WT}}$ tumors (HR 0.98; $95 \%$ CI $0.59-1.65 ; p=0.95$, Fig. 1f).

\section{hTERT promoter mutations, IDH1 mutations, and telomere length}

The incidence of TERTp ${ }^{\text {mut }}$ was $43 \%$ of which $84 \%$ harbored a C228T point mutation and $16 \%$ had a C250T point mutation (Supplementary Figure S2A) (Table 1). The presence of

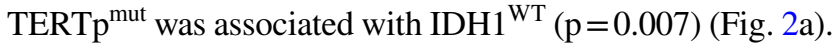

TERTp ${ }^{\text {mut }}$ tumors had slightly shorter CS-TL than TERTp $^{\text {WT }}$ tumors $(p=0.05)$ (Fig. $\left.2 b\right)$. When analyzing CS-TL according to IDH1 and TERTp ${ }^{\text {mut }}$ status, we confirmed the increased CS-TL of IDH1 ${ }^{\mathrm{R} 132}$ tumors but did not found significant differences of CS-TL beween IDH $1^{\mathrm{WT}}$ / TERTp $^{\text {WT }}$ and IDH $1^{\text {WT }} /$ TERTp $^{\text {mut }}$ or IDH $1^{\text {R132H }} /{ }^{\text {TERTp }}{ }^{\text {WT }}$ and IDH1 ${ }^{\text {R132H }} /$ TERTp $^{\text {mut }}$ tumors (Fig. 2c).

TERTp status was significantly associated with reduced survival (HR 2.05; 95\% CI 1.10-3.86; $p=0.022$ ) in the entire cohort (Fig. 2d). However, in patients with an IDH1 ${ }^{\mathrm{R} 132 \mathrm{H}}$ tumor, TERTp status did not significantly associate with survival (Fig. 2e), and multivariate analysis unveiled that TERTp status was not an independent prognostic factor when adjusting for age, WHO grade, and IDH1 status (HR 1.06 ; $95 \%$ CI $0.50-2.24 ; \mathrm{p}=0.87$ ).

\section{ALT, ATRX mutations and telomere length}

Using telomere FISH, we studied the presence of ALT (ALT ${ }^{\text {pos }}$ ) on a single cell level in our cohort (Fig. 3a). 37\% of the patients had ALT ${ }^{\text {pos }}$ tumors (Table 1) of which $100 \%$ also had an IDH1 ${ }^{\mathrm{R} 132 \mathrm{H}}$ mutation (Fig. 3b). Further, loss of ATRX expression (Fig. 3c) and TERTp ${ }^{\text {WT }}$ (Fig. 3d) were associated with the presence of ALT. Both, presence of ALT and loss of ATRX expression were significantly associated with longer telomeres $(\mathrm{p}<0.001$, Fig. $3 e, f)$ and improved survival (HR 0.42; 95\% CI 0.22-0.81; $\mathrm{p}=0.007$ and HR 0.46 ; 95\% CI 0.4-0.85; $\mathrm{p}=0.012$, respectively; Fig. 3g, h). However, this association disappeared when adjusting for age, WHO grade and IDH1 status i a multi-variate analysis (ALT status: HR 0.62; 95\% CI 0.23-1.72; $\mathrm{p}=0.36$; ATRX status: HR 1.12; 95\% CI 0.43-2.93; $\mathrm{p}=0.82$ ).

\section{In vitro overexpression of mutant IDH ${ }^{\mathrm{R} 132 \mathrm{H}}$ in a GBM cell line}

To understand the role of IDH $1^{\mathrm{R} 132 \mathrm{H}}$ mutations in regulating CS-TL in glioma, we used a doxycycline-inducible GBM cell line (LN319) expressing IDH $1^{\mathrm{WT}}$ and IDH1 ${ }^{\mathrm{R} 132 \mathrm{H}}$. The cell line was previously described and the presence of the IDH1 ${ }^{\mathrm{R} 132 \mathrm{H}}$ mutation was confirmed by sequencing [39]. $\mathrm{IDH}^{\mathrm{R} 132 \mathrm{H}}$ expression induced by doxycycline significantly stimulated D2HG synthesis ( $p=0.01$; Fig. 4a), and compromised proliferation and clonogenicity (Supplementary Figure S3A-B). In this in vitro model, induced IDH1 ${ }^{\mathrm{R} 132 \mathrm{H}}$ overexpression also resulted in a significant increase in TL after nine population doublings (Fig. 4b; Supplementary Figure S3C) and a significant downregulation of ATRX at transcriptional level (Fig. 4c). Telomere FISH detected a significant increase in ALT $^{\text {pos }}$ cells in IDH $1^{\mathrm{R} 132 \mathrm{H}}$ cells (Fig. 4d, left panels) and loss of ATRX protein expression 
A

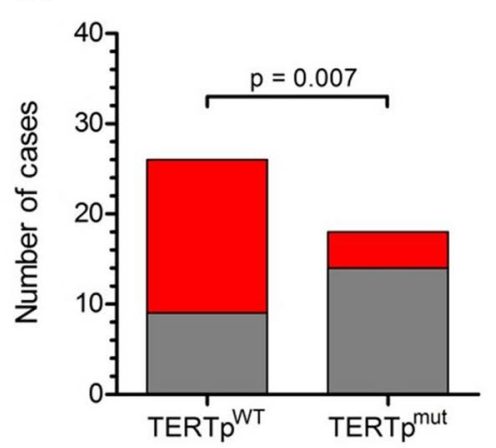

C
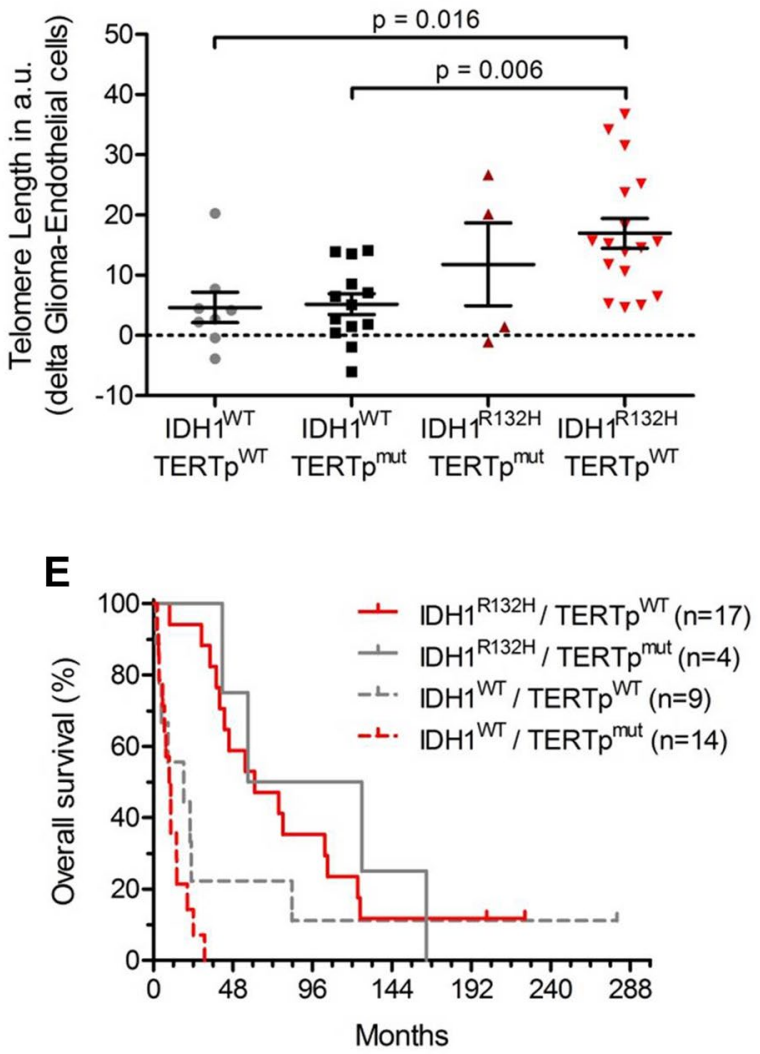

B

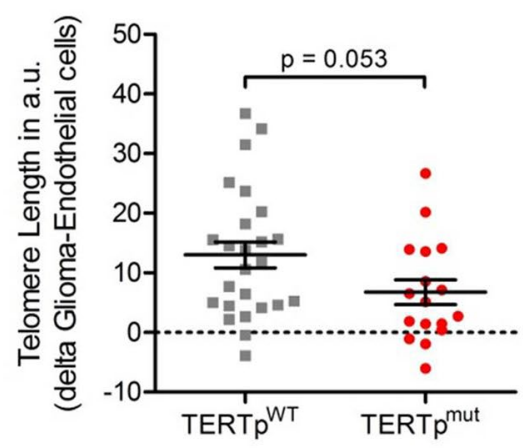

D

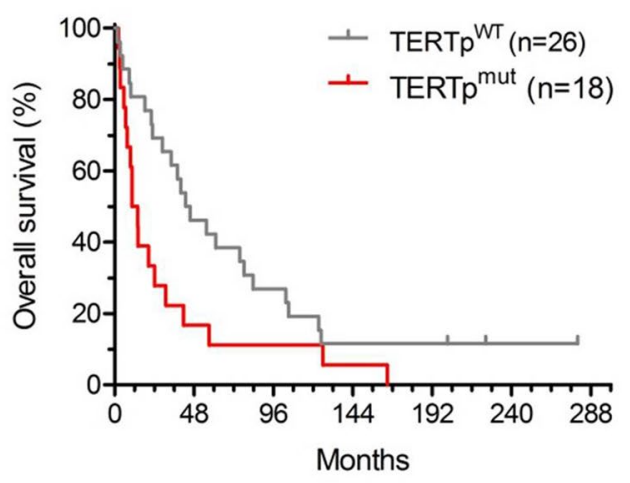

Fig. 2 TERT promotor, glioma cell-specific telomere length and IDH status. a Distribution of IDH $1^{\text {WT }}$ and $\mathrm{IDH} 1^{\mathrm{R} 132 \mathrm{H}}$ among the TERTp $^{\text {mut }}$ and TERTp ${ }^{\text {WT }}$ patients $\left(p=0.001, X^{2}\right.$-test $)$. b Gliomaspecific telomere length (CS-TL, in arbitrary units, a.u.) in TERTp ${ }^{\mathrm{WT}}$

(Fig. 4d) middle panels). Induced $\mathrm{IDH}^{\mathrm{R} 132 \mathrm{H}}$ overexpression neither altered the TERTp ${ }^{\text {mut }}$ status after short or and TERTp ${ }^{\text {mut }}$ tumors. c CS-TL (in a.u.) of glioma patients according to IDH1 and TERTp ${ }^{\text {mut }}$ status. d Kaplan-Meier survival curves of TERTp $^{\text {WT }}$ and TERTp ${ }^{\text {mut }}$ patients. e Kaplan-Meier survival curves of TERTp $^{\text {WT }}$ and TERTp ${ }^{\text {mut }}$ patients stratified after IDH1 status

long-term culture (Supplementary Figure S3D) nor significantly increased TERT mRNA expression level (Fig. 4e). 


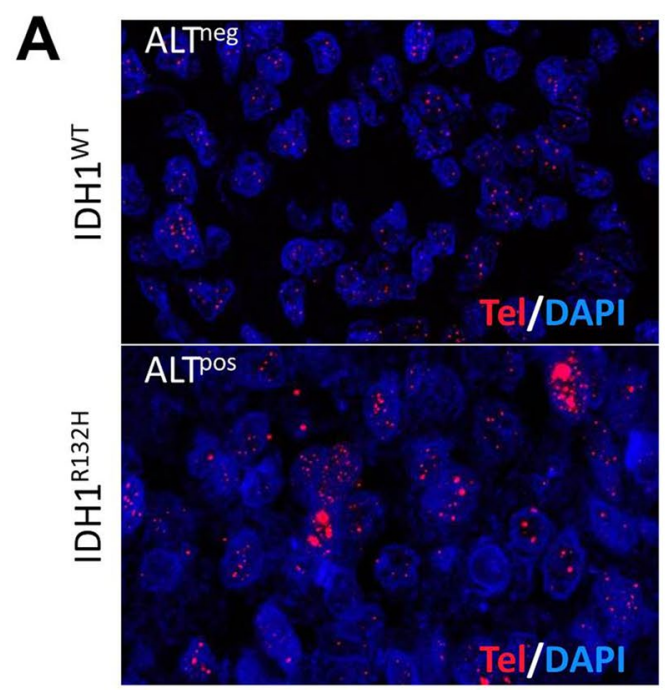

C

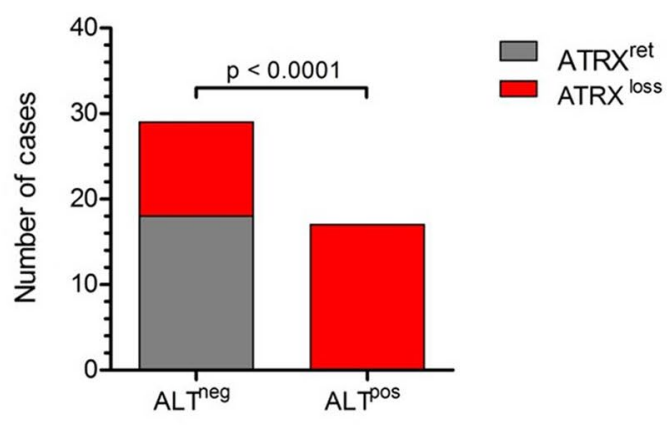

E

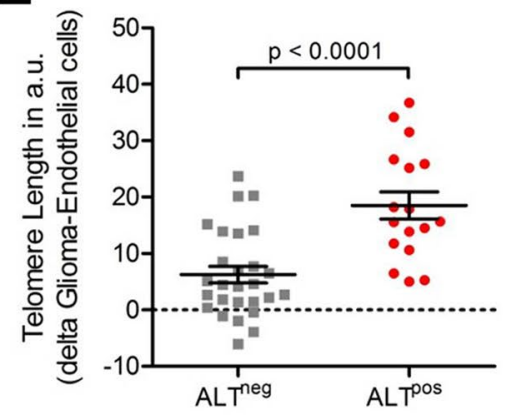

G

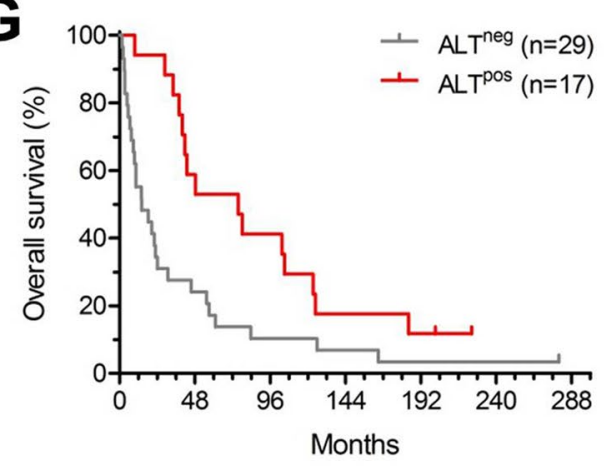

B

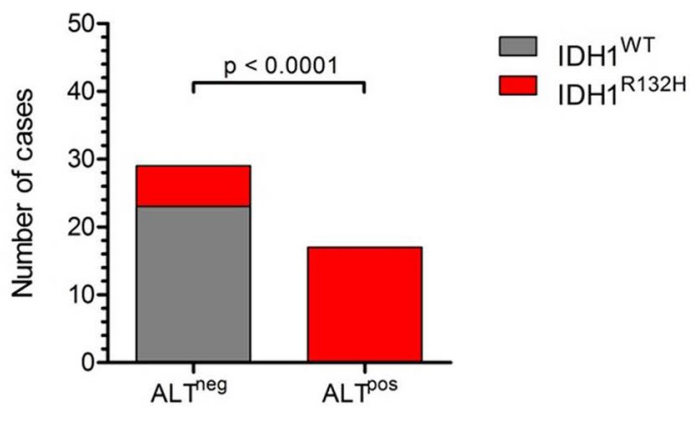

D

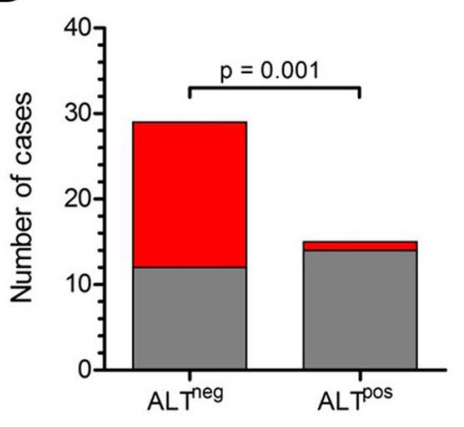

F

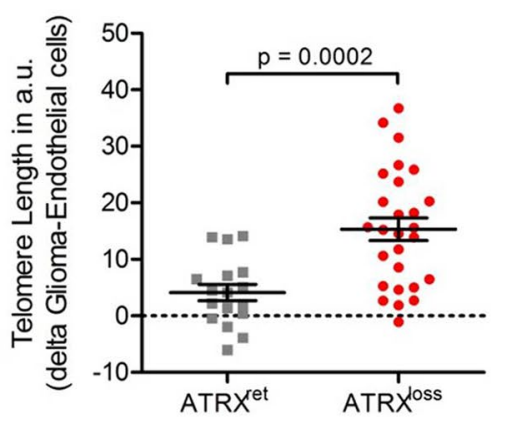

H

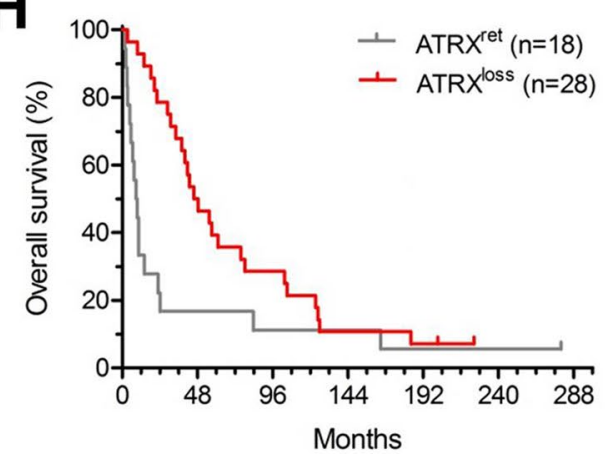


4Fig. 3 ATRX, alternative lengthening and survival. a Representative images showing Q-FISH stained gliomas with (ALT ${ }^{\mathrm{pos}}$ ) and without ALT (ALT ${ }^{\text {neg }}$, magnification: 756x). b Number of IDH1 ${ }^{\text {WT }}$ and IDH1 ${ }^{\text {R132 }}$ patients stratified according to ALT status. c Number of $\mathrm{ATRX}^{\mathrm{WT}}$ and $\mathrm{ATRX}^{\text {mut }}$ patients stratified according to ALT status. d Number of TERTp ${ }^{\text {WT }}$ and TERTp ${ }^{\text {mut }}$ patients stratified according to ALT status. e Glioma-specific telomere length (CS-TL in arbitrary units, a.u.) in $\mathrm{ALT}^{\text {neg }}$ and $\mathrm{ALT}^{\mathrm{pos}}$ tumors. f Glioma-specific telomere length (CS-TL in arbitrary units, a.u.) in tumors with retained (ATRX ${ }^{\text {ret }}$ ) ATRX and in tumors with ATRX loss $\left(\right.$ ALT $\left.^{\text {loss }}\right)$. $\mathbf{g}$ Kaplan-Meier survival curves (in months) of glioma patients according to ALT status. h Kaplan-Meier survival curves (in months) of glioma patients according to ATRX mutational status

Immunofluorescence for TERT protein expression with DAPI counterstaining (Fig. 4d, right panels) illustrated the TERT-independent increase of TL in IDH ${ }^{\mathrm{R} 132 \mathrm{H}}$ cells.

\section{Discussion}

Maintenance mechanisms of telomeres are promising therapeutic targets and small molecule telomerase inhibitors are currently tested in clinical trials and filed for approval for the treatment of myeloproliferative syndromes [40, 41]. Exact understanding of telomere biology in glioma is therefore of high translational importance, given the completely diverse prognostic impact of TERTp mutations according to the IDH1 mutation status. Here we provide evidence suggesting that glioma subgroups with and without IDH1 mutations use different TMM and describe a new pathway linking the IDH $1^{\text {R132H }}$ mutations to ALT.

One major limitation of published studies on telomere biology in solid cancer was missing availability of techniques that allow the determination of TL on a single cell level. In most studies performed so far [42-44], TL in tumor samples was actually derived from a mixture of vessels, immune cells and normal brain or tumor cells. This impaired significantly the validity and robustness of such studies. Furthermore, these studies rarely controlled for inter-individual (mostly genetic) variability of TL or the presence of ALT. In our study, we developed a modified immuno-Q-FISH technique for the determination of the TL in glioma cells at a single cell level, thus allowing to overcome some of these limitations not only by measuring tumor cells individually but also by using endogenous endothelial cells as nonmalignant controls. Using this technique, we could show an increased CS-TL in IDH1 ${ }^{\mathrm{R} 132 \mathrm{H}}$ mutated as compared to IDH $1^{\text {WT }}$ tumors.

Concerning the role of ARTX mutations in gliomas [21, 23, 26-28], we confirmed the association with survival[45] and with ALT[21] as well as the association among ALT, ATRX expression loss, and IDH1 ${ }^{\mathrm{R} 132 \mathrm{H}}$. However, the samples size of our cohort does not allow sound conclusions the prognostic relevance of the different TMM and the lacking association of ALT and TERTp mutations in the multivariate analysis have to be interpreted with caution. In line with Heidenreich et al. [42], our data supports the evidence that TERTp ${ }^{\text {mut }}$ are associated with shorter TL in gliomas.

Here we showed that the IDH $1^{\mathrm{R} 132 \mathrm{H}}$ mutation is directly associated with a lack of ATRX expression and consequently, ALT as described previously [46]. In our sample, all tumors with ALT bear IDH1 ${ }^{\mathrm{R} 132 \mathrm{H}}$ mutations and lost ATRX expression. Together with the inverse association of ALT with TERTp ${ }^{\text {mut }}$, our data suggests that ALT is the major TMM in IDH $1^{\mathrm{R} 132 \mathrm{H}}$ astrocytoma. Conversely, TERTp mutations appear to be the crucial TMM in IDH ${ }^{\mathrm{WT}}$ astrocytoma.

Our data suggests a dichotomy of mechanisms in astrocytoma depending on the presence of IDH1 mutations (Fig. 5). In one tumor with TERTp mutations and ALT, the co-existance of two distinct TMM in IDH1 ${ }^{\mathrm{R} 132 \mathrm{H}}$ cells of the same tumor (ALT and telomerase-dependent mechanisms) may exist, similar to the mosaic hypothesis previously suggested for other tumor types, e.g. sarcomas [47]. The proposed dichotomy indicates that treatment strategies targeting telomere maintenance, e.g. treatment with telomerase-inhibitors or ALT targeted treatment such e.g. PARP inhibitors or ATRX directed drugs [48, 49], must be personalized to the patient according to TMM. It is likely that the use of telomerase inhibitors can be ineffective or even detrimental in treating patients with $\mathrm{IDH}^{\mathrm{R} 132 \mathrm{H}}$ gliomas. Thus, the determination of ALT could be usefull as predictive marker to identify patients not responding to telomerase inhibitors.

We also showed that overexpression of IDH1 ${ }^{\mathrm{R} 132 \mathrm{H}}$ in glioma cells in vitro result in a phenotype that fully mimicked all phenomena observed in the patient samples. Overexpression of IDH $1^{\mathrm{R} 132 \mathrm{H}}$ in the glioma cells resulted in D2HG production, decreased proliferation in vitro, loss of ATRX expression in vitro and ALT. Reduced ATRX expression due to IDH $1^{\mathrm{R} 132 \mathrm{H}}$ overexpression suggests that IDH $1^{\mathrm{R} 132 \mathrm{H}}$ alone is sufficient to diminish ATRX expression and thereby induce ALT. However, the importance and functional relevance of this mechanism needs to be further confirmed in vivo. Further, it remains to be clarified, why $\operatorname{IDH}^{\mathrm{R} 132 \mathrm{H}}$ mutated glioma cells favor ATRX mutations, although there is a second, alternative pathway to suppress ATRX.

An obvious mechanism linking IDH $1^{\mathrm{R} 132 \mathrm{H}}$ phenotype to the loss of ATRX in human glioma may be the existence of a typical hypermethylation/CpG island methylation of the ATRX gene. Our data partially supports the results found by Ohba et al. [50], who showed that IDH1 mutations do not select for or induce ATRX mutations or TERTp ${ }^{\text {mut }}$. However, we found no significant reactivation of TERT.

In conclusion, we found that ALT is the major TMM in IDH $1^{\mathrm{R} 132 \mathrm{H}}$ astrocytomas and that IDH1 ${ }^{\mathrm{R} 132 \mathrm{H}}$ mutations can directly suppress ATRX expression resulting in ALT. 

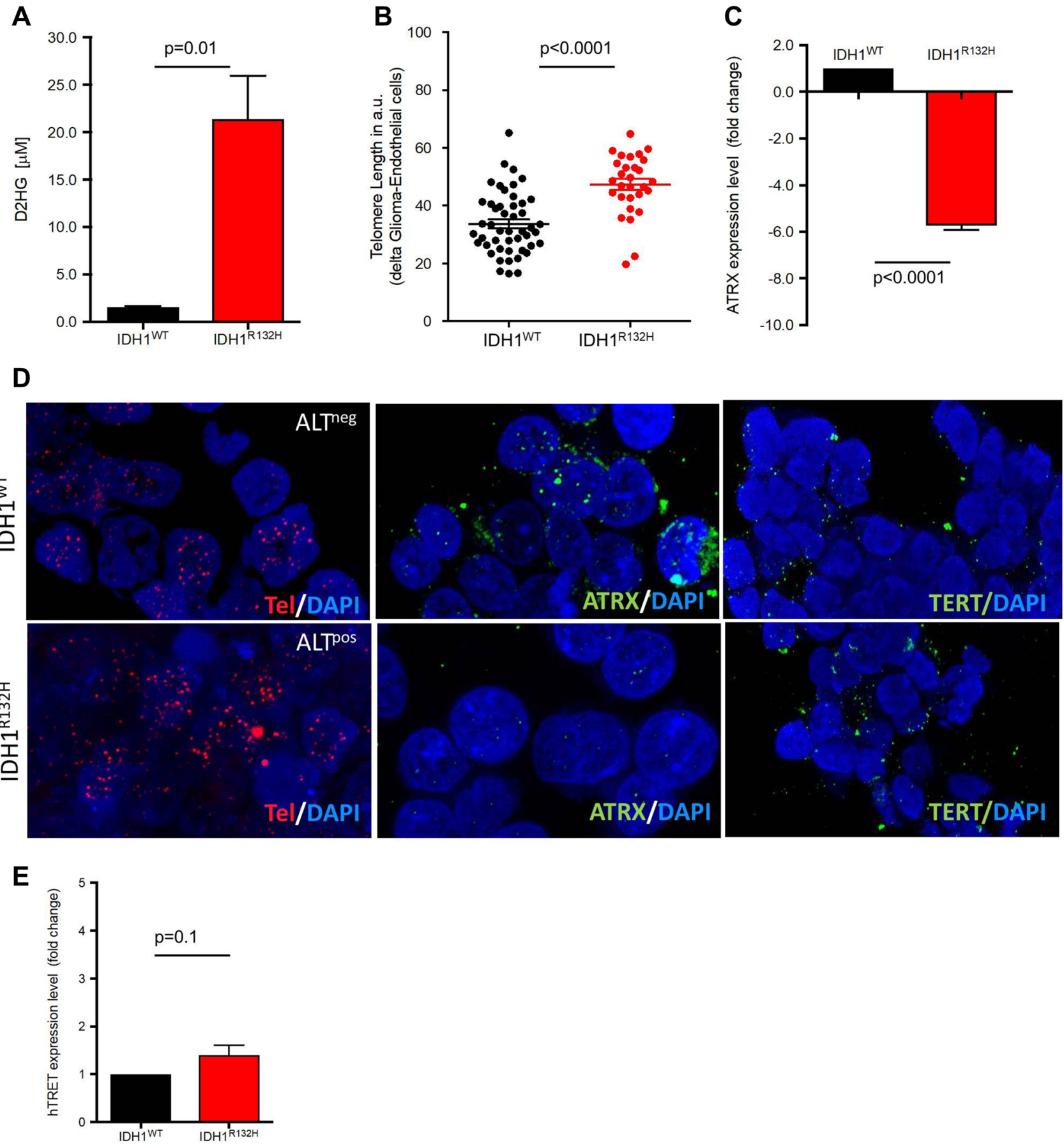

Fig. 4 Telomerelength after induction of $\mathrm{IDH} 1^{\mathrm{R} 132 \mathrm{H}}$ expression. a Production of the metabolite (inM) in the glioma cell line LN319 after the doxycycline-induced overexpression of $\mathrm{IDH} 1^{\mathrm{R} 132 \mathrm{H}}$ and control conditions. D2HG was measured in the medium supernatant after three population doublings in culture. b Telomere length in the doxycycline induced IDH $1^{\text {WT }}$ and $\mathrm{IDH} 1^{\mathrm{R} 132 \mathrm{H}}$ cell lines, after nine population doublings in culture $\left(\mathrm{IDH} 1^{\mathrm{WT}}=33.76 \pm 1.54\right.$ a.u, $\mathrm{n}=48$ vs. IDH1 $1^{\mathrm{R} 132 \mathrm{H}}=47.3 \pm 1.93$ a.u, $\mathrm{n}=29$ ). c Fold change of ATRX mRNA expression after doxycycline treatment and nine population doublings as compared to untreated controls. d Representative images of Q-FISH stained doxycycline induced IDH1 ${ }^{\text {WT }}$ (upper row) and IDH1 $1^{\mathrm{R} 132 \mathrm{H}}$ cell lines (lower row). All images correspond to cell culture after 14 population doublings. The presence of ALT (left panel: telomere FISH (red), DAPI counterstaining), ATRX protein expression (middle panel: ATRX immunofluorescence (green), DAPI counterstaining), and TERT expression (right panel: TERT immunofluorescence (green), DAPI counterstaining) is given (magnification 756x). e TERT expression levels (fold change) at the mRNA level of doxycycline-induced IDH1 $1^{\mathrm{WT}}$ and IDH1 $1^{\mathrm{R} 132 \mathrm{H}}$ cell lines after nine population doublings in culture 
Fig. 5 Overview of the two mechanisms of telomere maintenance. a Acquisition of IDH1 ${ }^{\mathrm{R} 132 \mathrm{H}}$ mutation leads to reduced ATRX expression and ALT. b Acquisition of TERTp $^{\text {mut }}$ mutation results in increased telomerase expression and telomere elongation via telomerase

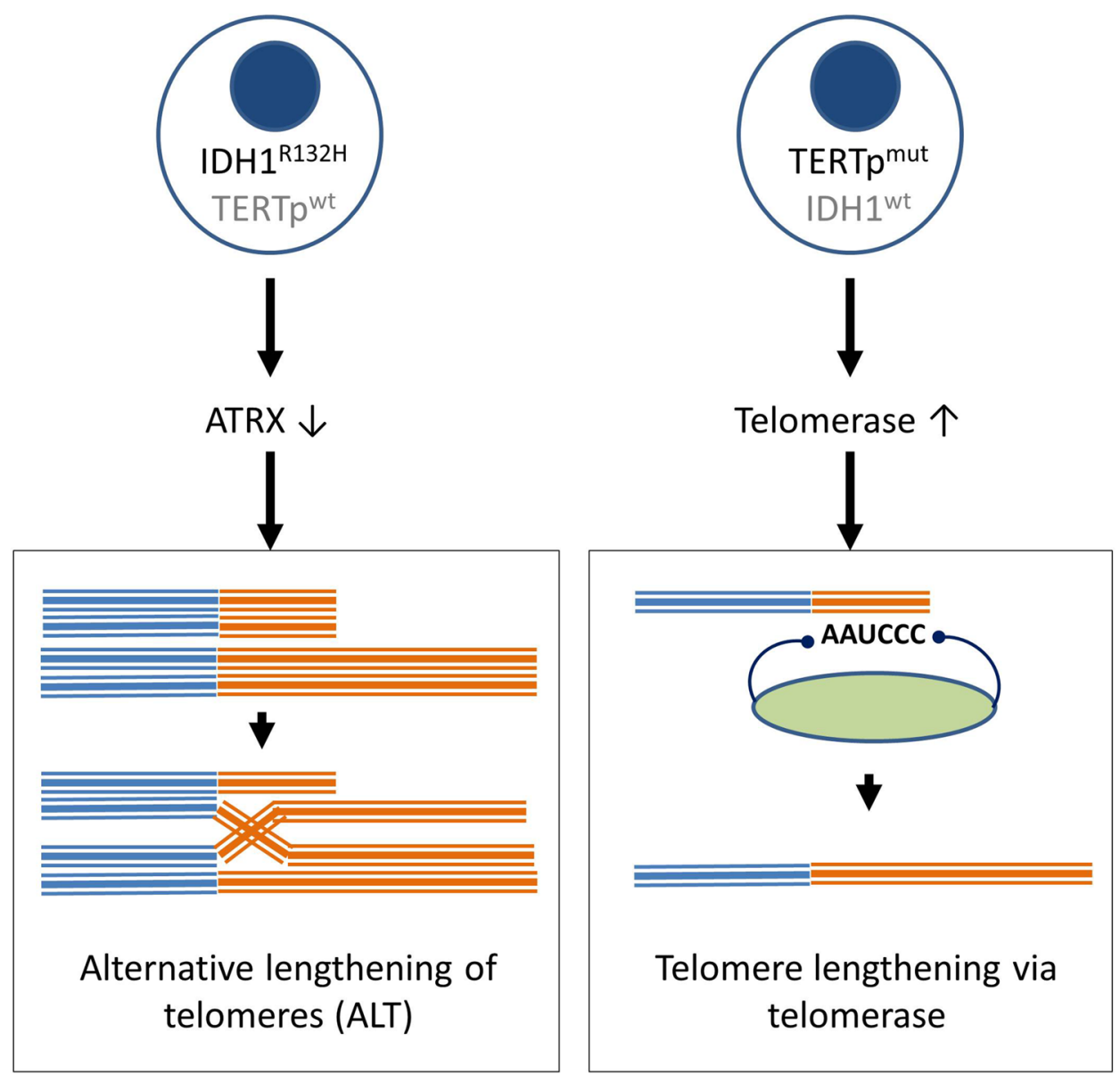

Acknowledgements Open Access funding provided by Projekt DEAL. We would like to thank Andreas von Deimling for his excellent comments on the manuscript. Further, we are thankful to Anne Abels for the excellent technical assistance.

Author contributions MSVF: Performed the experiments analyzed, interpreted the data and wrote the manuscript. MDS: Performed the IHC experiments, analyzed and interpreted the data, and revised the manuscript. SP: Provided and helped performing the $2 \mathrm{HG}$ and the LN319 IDH ${ }^{\mathrm{R} 132 \mathrm{H}}$ assays and revised the manuscript. DB: Provided clinical data and interpreted the data. ASB: performed experiments and analyzed the data. BWK: Provided patient samples, clinical data and interpreted the data. THB provided fincancial support, analyzed and interpreted the data and wrote the manuscript; FB, CPB conceived and planned the study design, interpreted the data, and wrote the manuscript.

Funding This work was supported by a Grant START grant (RWTH Aachen University) to M.S.V.F. and Region of Southern Denmark Grant to C.P.B. (17/18517).

\section{Compliance with ethical standards}

Conflict of interest Stefan Pusch is patent holder of a patient on the $2 \mathrm{HG}$ assay used in this manuscript. All terms concerning this patent are handled by the DKFZ Technology Transfer department. The other authors have nothing to disclose.

Open Access This article is licensed under a Creative Commons Attribution 4.0 International License, which permits use, sharing, adaptation, distribution and reproduction in any medium or format, as long as you give appropriate credit to the original author(s) and the source, provide a link to the Creative Commons licence, and indicate if changes were made. The images or other third party material in this article are included in the article's Creative Commons licence, unless indicated otherwise in a credit line to the material. If material is not included in the article's Creative Commons licence and your intended use is not permitted by statutory regulation or exceeds the permitted use, you will need to obtain permission directly from the copyright holder. To view a copy of this licence, visit http://creativecommons.org/licenses/by/4.0/.

\section{References}

1. Huse JT, Phillips HS, Brennan CW (2011) Molecular subclassification of diffuse gliomas: seeing order in the chaos. Glia 59:1190-1199. https://doi.org/10.1002/glia.21165

2. Louis DN, Perry A, Reifenberger G, von Deimling A, FigarellaBranger D, Cavenee WK, Ohgaki H, Wiestler OD, Kleihues P, Ellison DW (2016) The 2016 World Health Organization Classification of Tumors of the Central Nervous System: a summary. 
Acta Neuropathol 131:803-820. https://doi.org/10.1007/s0040 1-016-1545-1

3. Eckel-Passow JE, Lachance DH, Molinaro AM, Walsh KM, Decker PA, Sicotte H, Pekmezci M, Rice T, Kosel ML, Smirnov IV, Sarkar G, Caron AA, Kollmeyer TM, Praska CE, Chada AR, Halder C, Hansen HM, McCoy LS, Bracci PM, Marshall R, Zheng S, Reis GF, Pico AR, O’Neill BP, Buckner JC, Giannini C, Huse JT, Perry A, Tihan T, Berger MS, Chang SM, Prados MD, Wiemels J, Wiencke JK, Wrensch MR, Jenkins RB (2015) Glioma groups based on $1 \mathrm{p} / 19 \mathrm{q}$, IDH, and TERT promoter mutations in tumors. N Engl J Med 372:2499-2508. https://doi.org/10.1056/ NEJMoa1407279

4. Cancer Genome Atlas Research N, Brat DJ, Verhaak RG, Aldape KD, Yung WK, Salama SR, Cooper LA, Rheinbay E, Miller CR, Vitucci M, Morozova O, Robertson AG, Noushmehr H, Laird PW, Cherniack AD, Akbani R, Huse JT, Ciriello G, Poisson LM, Barnholtz-Sloan JS, Berger MS, Brennan C, Colen RR, Colman $\mathrm{H}$, Flanders AE, Giannini C, Grifford M, Iavarone A, Jain R, Joseph I, Kim J, Kasaian K, Mikkelsen T, Murray BA, O’Neill BP, Pachter L, Parsons DW, Sougnez C, Sulman EP, Vandenberg SR, Van Meir EG, von Deimling A, Zhang H, Crain D, Lau K, Mallery D, Morris S, Paulauskis J, Penny R, Shelton T, Sherman M, Yena P, Black A, Bowen J, Dicostanzo K, Gastier-Foster J, Leraas KM, Lichtenberg TM, Pierson CR, Ramirez NC, Taylor C, Weaver S, Wise L, Zmuda E, Davidsen T, Demchok JA, Eley G, Ferguson ML, Hutter CM, Mills Shaw KR, Ozenberger BA, Sheth M, Sofia HJ, Tarnuzzer R, Wang Z, Yang L, Zenklusen JC, Ayala B, Baboud J, Chudamani S, Jensen MA, Liu J, Pihl T, Raman R, Wan Y, Wu Y, Ally A, Auman JT, Balasundaram M, Balu S, Baylin SB, Beroukhim R, Bootwalla MS, Bowlby R, Bristow CA, Brooks D, Butterfield Y, Carlsen R, Carter S, Chin L, Chu A, Chuah E, Cibulskis K, Clarke A, Coetzee SG, Dhalla N, Fennell T, Fisher S, Gabriel S, Getz G, Gibbs R, Guin R, Hadjipanayis A, Hayes DN, Hinoue T, Hoadley K, Holt RA, Hoyle AP, Jefferys SR, Jones S, Jones CD, Kucherlapati R, Lai PH, Lander E, Lee S, Lichtenstein L, Ma Y, Maglinte DT, Mahadeshwar HS, Marra MA, Mayo M, Meng S, Meyerson ML, Mieczkowski PA, Moore RA, Mose LE, Mungall AJ, Pantazi A, Parfenov M, Park PJ, Parker JS, Perou CM, Protopopov A, Ren X, Roach J, Sabedot TS, Schein J, Schumacher SE, Seidman JG, Seth S, Shen H, Simons JV, Sipahimalani P, Soloway MG, Song X, Sun H, Tabak B, Tam A, Tan D, Tang J, Thiessen N, Triche T Jr, Van Den Berg DJ, Veluvolu U, Waring S, Weisenberger DJ, Wilkerson MD, Wong T, Wu J, Xi L, Xu AW, Yang L, Zack TI, Zhang J, Aksoy BA, Arachchi H, Benz C, Bernard B, Carlin D, Cho J, DiCara D, Frazer S, Fuller GN, Gao J, Gehlenborg N, Haussler D, Heiman DI, Iype L, Jacobsen A, Ju Z, Katzman S, Kim H, Knijnenburg T, Kreisberg RB, Lawrence MS, Lee W, Leinonen K, Lin P, Ling S, Liu W, Liu Y, Liu Y, Lu Y, Mills G, Ng S, Noble MS, Paull E, Rao A, Reynolds S, Saksena G, Sanborn Z, Sander C, Schultz N, Senbabaoglu Y, Shen R, Shmulevich I, Sinha R, Stuart J, Sumer SO, Sun Y, Tasman N, Taylor BS, Voet D, Weinhold N, Weinstein JN, Yang D, Yoshihara K, Zheng S, Zhang W, Zou L, Abel T, Sadeghi S, Cohen ML, Eschbacher J, Hattab EM, Raghunathan A, Schniederjan MJ, Aziz D, Barnett G, Barrett W, Bigner DD, Boice L, Brewer C, Calatozzolo C, Campos B, Carlotti CG Jr, Chan TA, Cuppini L, Curley E, Cuzzubbo S, Devine K, DiMeco F, Duell R, Elder JB, Fehrenbach A, Finocchiaro G, Friedman W, Fulop J, Gardner J, Hermes B, Herold-Mende C, Jungk C, Kendler A, Lehman NL, Lipp E, Liu O, Mandt R, McGraw M, McLendon R, McPherson C, Neder L, Nguyen P, Noss A, Nunziata R, Ostrom QT, Palmer C, Perin A, Pollo B, Potapov A, Potapova O, Rathmell WK, Rotin D, Scarpace L, Schilero C, Senecal K, Shimmel K, Shurkhay V, Sifri S, Singh R, Sloan AE, Smolenski K, Staugaitis SM, Steele R, Thorne L, Tirapelli DP, Unterberg A, Vallurupalli M, Wang Y, Warnick R, Williams F, Wolinsky Y, Bell
S, Rosenberg M, Stewart C, Huang F, Grimsby JL, Radenbaugh AJ, Zhang J (2015) Comprehensive, integrative genomic analysis of diffuse lower-grade gliomas. N Engl J Med 372:2481-2498. https://doi.org/10.1056/NEJMoa1402121

5. Yan H, Parsons DW, Jin G, McLendon R, Rasheed BA, Yuan W, Kos I, Batinic-Haberle I, Jones S, Riggins GJ, Friedman H, Friedman A, Reardon D, Herndon J, Kinzler KW, Velculescu VE, Vogelstein B, Bigner DD (2009) IDH1 and IDH2 mutations in gliomas. N Engl J Med 360:765-773. https://doi.org/10.1056/ NEJMoa0808710

6. Dunn GP, Andronesi OC, Cahill DP (2013) From genomics to the clinic: biological and translational insights of mutant IDH1/2 in glioma. Neurosurg Focus 34:E2. https://doi.org/10.3171/2012.12. FOCUS12355

7. Metallo CM, Gameiro PA, Bell EL, Mattaini KR, Yang J, Hiller K, Jewell CM, Johnson ZR, Irvine DJ, Guarente L, Kelleher JK, Vander Heiden MG, Iliopoulos O, Stephanopoulos G (2011) Reductive glutamine metabolism by IDH1 mediates lipogenesis under hypoxia. Nature 481:380-384. https://doi.org/10.1038/ nature 10602

8. Nobusawa S, Watanabe T, Kleihues P, Ohgaki H (2009) IDH1 mutations as molecular signature and predictive factor of secondary glioblastomas. Clin Cancer Res 15:6002-6007. https:// doi.org/10.1158/1078-0432.CCR-09-0715

9. Pusch S, Schweizer L, Beck AC, Lehmler JM, Weissert S, Balss J, Miller AK, von Deimling A (2014) D-2-hydroxyglutarate producing neo-enzymatic activity inversely correlates with frequency of the type of isocitrate dehydrogenase 1 mutations found in glioma. Acta Neuropathol Commun 2:19. https://doi. org/10.1186/2051-5960-2-19

10. Xu W, Yang H, Liu Y, Yang Y, Wang P, Kim SH, Ito S, Yang C, Wang P, Xiao MT, Liu LX, Jiang WQ, Liu J, Zhang JY, Wang B, Frye S, Zhang Y, Xu YH, Lei QY, Guan KL, Zhao SM, Xiong Y (2011) Oncometabolite 2-hydroxyglutarate is a competitive inhibitor of alpha-ketoglutarate-dependent dioxygenases. Cancer Cell 19:17-30. https://doi.org/10.1016/j.ccr.2010.12.014

11. Noushmehr H, Weisenberger DJ, Diefes K, Phillips HS, Pujara K, Berman BP, Pan F, Pelloski CE, Sulman EP, Bhat KP, Verhaak RG, Hoadley KA, Hayes DN, Perou CM, Schmidt HK, Ding L, Wilson RK, Van Den Berg D, Shen H, Bengtsson H, Neuvial P, Cope LM, Buckley J, Herman JG, Baylin SB, Laird PW, Aldape K (2010) Identification of a CpG island methylator phenotype that defines a distinct subgroup of glioma. Cancer Cell 17:510-522. https://doi.org/10.1016/j.ccr.2010.03.017

12. Turcan S, Rohle D, Goenka A, Walsh LA, Fang F, Yilmaz E, Campos C, Fabius AW, Lu C, Ward PS, Thompson CB, Kaufman A, Guryanova O, Levine R, Heguy A, Viale A, Morris LG, Huse JT, Mellinghoff IK, Chan TA (2012) IDH1 mutation is sufficient to establish the glioma hypermethylator phenotype. Nature 483:479-483. https://doi.org/10.1038/nature10866

13. Blackburn EH (2005) Telomeres and telomerase: their mechanisms of action and the effects of altering their functions. FEBS Lett 579:859-862

14. Yuan P, Cao JL, Abuduwufuer A, Wang LM, Yuan XS, Lv W, Hu J (2016) Clinical characteristics and prognostic significance of TERT promoter mutations in cancer: a cohort study and a meta-analysis. PLoS ONE 11:e0146803. https://doi. org/10.1371/journal.pone.0146803

15. Ceccarelli M, Barthel FP, Malta TM, Sabedot TS, Salama SR, Murray BA, Morozova O, Newton Y, Radenbaugh A, Pagnotta SM, Anjum S, Wang J, Manyam G, Zoppoli P, Ling S, Rao AA, Grifford M, Cherniack AD, Zhang H, Poisson L, Carlotti CG Jr, Tirapelli DP, Rao A, Mikkelsen T, Lau CC, Yung WK, Rabadan R, Huse J, Brat DJ, Lehman NL, Barnholtz-Sloan JS, Zheng S, Hess K, Rao G, Meyerson M, Beroukhim R, Cooper L, Akbani R, Wrensch M, Haussler D, Aldape KD, Laird PW, 
Gutmann DH, Network TR, Noushmehr H, Iavarone A, Verhaak RG (2016) Molecular profiling reveals biologically discrete subsets and pathways of progression in diffuse glioma. Cell 164:550-563. https://doi.org/10.1016/j.cell.2015.12.028

16. Arita H, Narita Y, Fukushima S, Tateishi K, Matsushita Y, Yoshida A, Miyakita Y, Ohno M, Collins VP, Kawahara N, Shibui S, Ichimura K (2013) Upregulating mutations in the TERT promoter commonly occur in adult malignant gliomas and are strongly associated with total $1 \mathrm{p} 19 \mathrm{q}$ loss. Acta Neuropathol 126:267-276. https://doi.org/10.1007/s0040 1-013-1141-6

17. Hiraga S, Ohnishi T, Izumoto S, Miyahara E, Kanemura Y, Matsumura $\mathrm{H}$, Arita N (1998) Telomerase activity and alterations in telomere length in human brain tumors. Cancer Res 58:2117-2125

18. Cesare AJ, Reddel RR (2010) Alternative lengthening of telomeres: models, mechanisms and implications. Nat Rev Genet 11:319-330. https://doi.org/10.1038/nrg2763

19. Langford LA, Piatyszek MA, Xu R, Schold SC Jr, Shay JW (1995) Telomerase activity in human brain tumours. Lancet 346:1267-1268

20. Heaphy CM, Subhawong AP, Hong SM, Goggins MG, Montgomery EA, Gabrielson E, Netto GJ, Epstein JI, Lotan TL, Westra WH, Shih Ie M, Iacobuzio-Donahue CA, Maitra A, Li QK, Eberhart CG, Taube JM, Rakheja D, Kurman RJ, Wu TC, Roden RB, Argani P, De Marzo AM, Terracciano L, Torbenson M, Meeker AK (2011) Prevalence of the alternative lengthening of telomeres telomere maintenance mechanism in human cancer subtypes. Am J Pathol 179:1608-1615. https://doi.org/10.1016/j. ajpath.2011.06.018

21. Heaphy CM, de Wilde RF, Jiao Y, Klein AP, Edil BH, Shi C, Bettegowda C, Rodriguez FJ, Eberhart CG, Hebbar S, Offerhaus GJ, McLendon R, Rasheed BA, He Y, Yan H, Bigner DD, Oba-Shinjo SM, Marie SK, Riggins GJ, Kinzler KW, Vogelstein B, Hruban RH, Maitra A, Papadopoulos N, Meeker AK (2011) Altered telomeres in tumors with ATRX and DAXX mutations. Science 333:425. https://doi.org/10.1126/science.1207313

22. Lovejoy CA, Li W, Reisenweber S, Thongthip S, Bruno J, de Lange T, De S, Petrini JH, Sung PA, Jasin M, Rosenbluh J, Zwang Y, Weir BA, Hatton C, Ivanova E, Macconaill L, Hanna M, Hahn WC, Lue NF, Reddel RR, Jiao Y, Kinzler K, Vogelstein B, Papadopoulos N, Meeker AK, Consortium ALTSC (2012) Loss of ATRX, genome instability, and an altered DNA damage response are hallmarks of the alternative lengthening of telomeres pathway. PLoS Genet 8:e1002772. https://doi.org/10.1371/journ al.pgen. 1002772

23. Schwartzentruber J, Korshunov A, Liu XY, Jones DT, Pfaff E, Jacob K, Sturm D, Fontebasso AM, Quang DA, Tonjes M, Hovestadt V, Albrecht S, Kool M, Nantel A, Konermann C, Lindroth A, Jager N, Rausch T, Ryzhova M, Korbel JO, Hielscher T, Hauser P, Garami M, Klekner A, Bognar L, Ebinger M, Schuhmann MU, Scheurlen W, Pekrun A, Fruhwald MC, Roggendorf W, Kramm C, Durken M, Atkinson J, Lepage P, Montpetit A, Zakrzewska M, Zakrzewski K, Liberski PP, Dong Z, Siegel P, Kulozik AE, Zapatka M, Guha A, Malkin D, Felsberg J, Reifenberger G, von Deimling A, Ichimura K, Collins VP, Witt H, Milde T, Witt O, Zhang C, Castelo-Branco P, Lichter P, Faury D, Tabori U, Plass C, Majewski J, Pfister SM, Jabado N (2012) Driver mutations in histone $\mathrm{H} 3.3$ and chromatin remodelling genes in paediatric glioblastoma. Nature 482:226-231. https://doi.org/10.1038/natur e10833

24. Goldberg AD, Banaszynski LA, Noh KM, Lewis PW, Elsaesser SJ, Stadler S, Dewell S, Law M, Guo X, Li X, Wen D, Chapgier A, DeKelver RC, Miller JC, Lee YL, Boydston EA, Holmes MC, Gregory PD, Greally JM, Rafii S, Yang C, Scambler PJ, Garrick D, Gibbons RJ, Higgs DR, Cristea IM, Urnov FD, Zheng D, Allis CD (2010) Distinct factors control histone variant H3.3 localization at specific genomic regions. Cell 140:678-691. https ://doi.org/10.1016/j.cell.2010.01.003

25. Lewis PW, Elsaesser SJ, Noh KM, Stadler SC, Allis CD (2010) Daxx is an H3.3-specific histone chaperone and cooperates with ATRX in replication-independent chromatin assembly at telomeres. Proc Natl Acad Sci USA 107:14075-14080. https://doi. org/10.1073/pnas.1008850107

26. Jiao Y, Killela PJ, Reitman ZJ, Rasheed AB, Heaphy CM, de Wilde RF, Rodriguez FJ, Rosemberg S, Oba-Shinjo SM, Nagahashi Marie SK, Bettegowda C, Agrawal N, Lipp E, Pirozzi C, Lopez G, He Y, Friedman H, Friedman AH, Riggins GJ, Holdhoff M, Burger P, McLendon R, Bigner DD, Vogelstein B, Meeker AK, Kinzler KW, Papadopoulos N, Diaz LA, Yan H (2012) Frequent ATRX, CIC, FUBP1 and IDH1 mutations refine the classification of malignant gliomas. Oncotarget 3:709-722. https://doi.org/10.18632/oncotarget .588

27. Kannan K, Inagaki A, Silber J, Gorovets D, Zhang J, Kastenhuber ER, Heguy A, Petrini JH, Chan TA, Huse JT (2012) Whole-exome sequencing identifies ATRX mutation as a key molecular determinant in lower-grade glioma. Oncotarget 3:1194-1203. https://doi. org/10.18632/oncotarget.689

28. Liu XY, Gerges N, Korshunov A, Sabha N, Khuong-Quang DA, Fontebasso AM, Fleming A, Hadjadj D, Schwartzentruber J, Majewski J, Dong Z, Siegel P, Albrecht S, Croul S, Jones DT, Kool M, Tonjes M, Reifenberger G, Faury D, Zadeh G, Pfister S, Jabado N (2012) Frequent ATRX mutations and loss of expression in adult diffuse astrocytic tumors carrying IDH1/IDH2 and TP53 mutations. Acta Neuropathol 124:615-625. https://doi.org/10.1007/s0040 1-012-1031-3

29. Sorensen MD, Dahlrot RH, Boldt HB, Hansen S, Kristensen BW (2018) Tumour-associated microglia/macrophages predict poor prognosis in high-grade gliomas and correlate with an aggressive tumour subtype. Neuropathol Appl Neurobiol 44:185-206. https:// doi.org/10.1111/nan.12428

30. Dahlrot RH, Kristensen BW, Hjelmborg J, Herrstedt J, Hansen S (2013) A population-based study of high-grade gliomas and mutated isocitrate dehydrogenase 1. Int J Clin Exp Pathol 6:31-40

31. Ferreira MSV, Crysandt M, Braunschweig T, Jost E, Voss B, Bouillon AS, Knuechel R, Brummendorf TH, Beier F (2018) Presence of TERT promoter mutations is a secondary event and associates with elongated telomere length in myxoid liposarcomas. Int J Mol Sci. https://doi.org/10.3390/ijms19020608

32. Ventura Ferreira MS, Bienert M, Muller K, Rath B, Goecke T, Oplander C, Braunschweig T, Mela P, Brummendorf TH, Beier F, Neuss S (2018) Comprehensive characterization of chorionic villiderived mesenchymal stromal cells from human placenta. Stem Cell Res Ther 9:28. https://doi.org/10.1186/s13287-017-0757-1

33. Hummel S, Ventura Ferreira MS, Heudobler D, Huber E, Fahrenkamp D, Gremse F, Schmid K, Muller-Newen G, Ziegler P, Jost E, Blasco MA, Brummendorf TH, Holler E, Beier F (2015) Telomere shortening in enterocytes of patients with uncontrolled acute intestinal graft-versus-host disease. Blood 126:2518-2521. https://doi. org/10.1182/blood-2015-03-633289

34. Ziegler S, Schettgen T, Beier F, Wilop S, Quinete N, Esser A, Masouleh BK, Ferreira MS, Vankann L, Uciechowski P, Rink L, Kraus T, Brummendorf TH, Ziegler P (2017) Accelerated telomere shortening in peripheral blood lymphocytes after occupational polychlorinated biphenyls exposure. Arch Toxicol 91:289-300. https:// doi.org/10.1007/s00204-016-1725-8

35. Beier F, Foronda M, Martinez P, Blasco MA (2012) Conditional TRF1 knockout in the hematopoietic compartment leads to bone marrow failure and recapitulates clinical features of dyskeratosis congenita. Blood 120:2990-3000

36. Beier F, Balabanov S, Buckley T, Dietz K, Hartmann U, Rojewski M, Kanz L, Schrezenmeier H, Brummendorf TH (2005) Accelerated telomere shortening in glycosylphosphatidylinositol (GPI)-negative 
compared with GPI-positive granulocytes from patients with paroxysmal nocturnal hemoglobinuria $(\mathrm{PNH})$ detected by proaerolysin flow-FISH. Blood 106:531-533

37. Beier F, Martinez P, Blasco MA (2015) Chronic replicative stress induced by $\mathrm{CCl} 4$ in TRF1 knockout mice recapitulates the origin of large liver cell changes. J Hepatol 63:446-455

38. Beier F, Masouleh BK, Buesche G, Ventura Ferreira MS, Schneider RK, Ziegler P, Wilop S, Vankann L, Gattermann N, Platzbecker U, Giagounidis A, Gotze KS, Nolte F, Hofmann WK, Haase D, Kreipe H, Panse J, Blasco MA, Germing U, Brummendorf TH (2015) Telomere dynamics in patients with del (5q) MDS before and under treatment with lenalidomide. Leuk Res. https://doi.org/10.1016/j. leukres.2015.09.003

39. Birner P, Pusch S, Christov C, Mihaylova S, Toumangelova-Uzeir K, Natchev S, Schoppmann SF, Tchorbanov A, Streubel B, Tuettenberg J, Guentchev M (2014) Mutant IDH1 inhibits PI3K/Akt signaling in human glioma. Cancer 120:2440-2447. https://doi.org/10.1002/ cncr.28732

40. Tefferi A, Lasho TL, Begna KH, Patnaik MM, Zblewski DL, Finke CM, Laborde RR, Wassie E, Schimek L, Hanson CA, Gangat N, Wang X, Pardanani A (2015) A pilot study of the telomerase inhibitor imetelstat for myelofibrosis. N Engl J Med 373:908-919

41. Baerlocher GM, Oppliger Leibundgut E, Ottmann OG, Spitzer G, Odenike O, McDevitt MA, Roth A, Daskalakis M, Burington B, Stuart M, Snyder DS (2015) Telomerase inhibitor imetelstat in patients with essential thrombocythemia. N Engl J Med 373:920-928

42. Heidenreich B, Rachakonda PS, Hosen I, Volz F, Hemminki K, Weyerbrock A, Kumar R (2015) TERT promoter mutations and telomere length in adult malignant gliomas and recurrences. Oncotarget 6:10617-10633. https://doi.org/10.18632/oncotarget.3329

43. Gao K, Li G, Qu Y, Wang M, Cui B, Ji M, Shi B, Hou P (2016) TERT promoter mutations and long telomere length predict poor survival and radiotherapy resistance in gliomas. Oncotarget 7:87128725. https://doi.org/10.18632/oncotarget.6007

44. Wang S, Chen Y, Qu F, He S, Huang X, Jiang H, Jin T, Wan S, Xing J (2014) Association between leukocyte telomere length and glioma risk: a case-control study. Neuro-Oncol 16:505-512. https ://doi.org/10.1093/neuonc/not240

45. Pekmezci M, Rice T, Molinaro AM, Walsh KM, Decker PA, Hansen H, Sicotte H, Kollmeyer TM, McCoy LS, Sarkar G, Perry
A, Giannini C, Tihan T, Berger MS, Wiemels JL, Bracci PM, EckelPassow JE, Lachance DH, Clarke J, Taylor JW, Luks T, Wiencke JK, Jenkins RB, Wrensch MR (2017) Adult infiltrating gliomas with WHO 2016 integrated diagnosis: additional prognostic roles of ATRX and TERT. Acta Neuropathol 133:1001-1016. https://doi. org/10.1007/s00401-017-1690-1

46. Mukherjee J, Johannessen T-CA, Ohba S, Chow TT, Jones LE, Pandita A, Pieper RO (2018) Mutant IDH1 cooperates with ATRX loss to drive the alternative lengthening of telomere (ALT) phenotype in glioma. Cancer Res. https://doi.org/10.1158/0008-5472.can-17-2269

47. Gocha AR, Nuovo G, Iwenofu OH, Groden J (2013) Human sarcomas are mosaic for telomerase-dependent and telomerase-independent telomere maintenance mechanisms: implications for telomerebased therapies. Am J Pathol 182:41-48. https://doi.org/10.1016/j. ajpath.2012.10.001

48. Kovatcheva M, Liao W, Klein ME, Robine N, Geiger H, Crago AM, Dickson MA, Tap WD, Singer S, Koff A (2017) ATRX is a regulator of therapy induced senescence in human cells. Nat Commun 8:386. https://doi.org/10.1038/s41467-017-00540-5

49. Koschmann C, Calinescu AA, Nunez FJ, Mackay A, Fazal-Salom J, Thomas D, Mendez F, Kamran N, Dzaman M, Mulpuri L, Krasinkiewicz J, Doherty R, Lemons R, Brosnan-Cashman JA, Li Y, Roh S, Zhao L, Appelman H, Ferguson D, Gorbunova V, Meeker A, Jones C, Lowenstein PR, Castro MG (2016) ATRX loss promotes tumor growth and impairs nonhomologous end joining DNA repair in glioma. Sci Transl Med 8:328ra328. https://doi.org/10.1126/scitr anslmed.aac8228

50. Ohba S, Mukherjee J, Johannessen TC, Mancini A, Chow TT, Wood M, Jones L, Mazor T, Marshall RE, Viswanath P, Walsh KM, Perry A, Bell RJ, Phillips JJ, Costello JF, Ronen SM, Pieper RO (2016) Mutant IDH1 expression drives TERT promoter reactivation as part of the cellular transformation process. Cancer Res 76:6680-6689. https://doi.org/10.1158/0008-5472.CAN-16-0696

Publisher's Note Springer Nature remains neutral with regard to jurisdictional claims in published maps and institutional affiliations. 